\begin{tabular}{|l|l|l||}
\hline \multicolumn{2}{|c|}{ PublisherInfo } \\
\hline \hline PublisherName & $:$ & BioMed Central \\
\hline \hline PublisherLocation & $:$ & London \\
\hline \hline PublisherImprintName & $:$ & BioMed Central \\
\hline \hline
\end{tabular}

\title{
Early globetrotters
}

\begin{tabular}{|l|l|l||}
\hline \multicolumn{2}{|c|}{ ArticleInfo } \\
\hline \hline ArticleID & $:$ & 3732 \\
\hline \hline ArticleDOI & $:$ & $10.1186 /$ gb-spotlight-20000725-02 \\
\hline \hline ArticleCitationID & $:$ & spotlight-20000725-02 \\
\hline \hline ArticleSequenceNumber & $:$ & 169 \\
\hline \hline ArticleCategory & $:$ & Research news \\
\hline ArticleFirstPage & $:$ & 1 \\
\hline \hline ArticleLastPage & $:$ & 2 \\
\hline \hline & & RegistrationDate : 2000-07-25 \\
ArticleHistory & $:$ & OnlineDate $\quad 2000-07-25$ \\
\hline \hline ArticleCopyright & $:$ & BioMed Central Ltd2000 \\
\hline \hline ArticleGrants & $:$ & \\
\hline \hline ArticleContext & $:$ & 130591111 \\
\hline \hline
\end{tabular}




\section{William Wells}

Email: wells@biotext.com

Were the Pacific islands of Polynesia colonized by people migrating from Taiwan or Melanesia? Su et al. suggest in the July 18 Proceedings of the National Academy of Sciences that neither theory is correct, and that southeast Asia may have been the starting-off point (Proc. Natl. Acad. Sci. USA 2000, 97:8225-8228). They base their claims on haplotypes from the nonrecombining portion of the $\mathrm{Y}$ chromosome. Only one Polynesian haplotype is shared with the Taiwanese, whereas nine of ten Pacific island haplotypes are also found in southeast Asians. The tenth, unique haplotype is specific to Melanesia, which suggests either that Polynesians did not come via Melanesia, or that a population bottleneck extinguished the haplotype during the final migration.

\section{References}

1. The origins of the Polynesians: an interpretation from mitochondrial lineage analysis.

2. Proceedings of the National Academy of Sciences, [http://www.pnas.org/] 